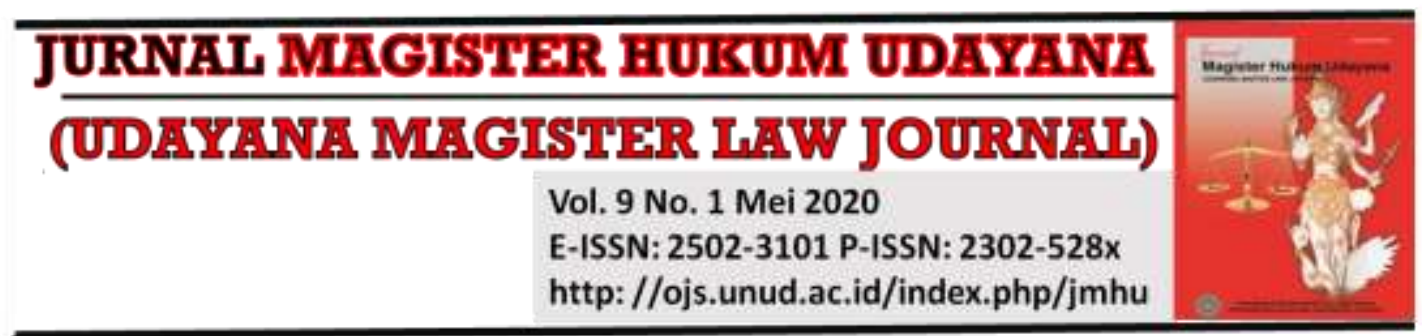

\title{
Pengaturan Lembaga Gadai Online dalam Dimensi 4.0 di Indonesia
}

\section{Putu Dinanda Prajna Putri ${ }^{1}$, I Made Sarjana²}

${ }^{1}$ Dinas Pekerjaan Umum, Penataan Ruang, Perumahan dan Kawasan Permukiman Provinsi

Bali, E-mail: dinandaputri29@gmail.com

2Fakultas Hukum Universitas Udayana, E-mail: made.sarjana@yahoo.co.id

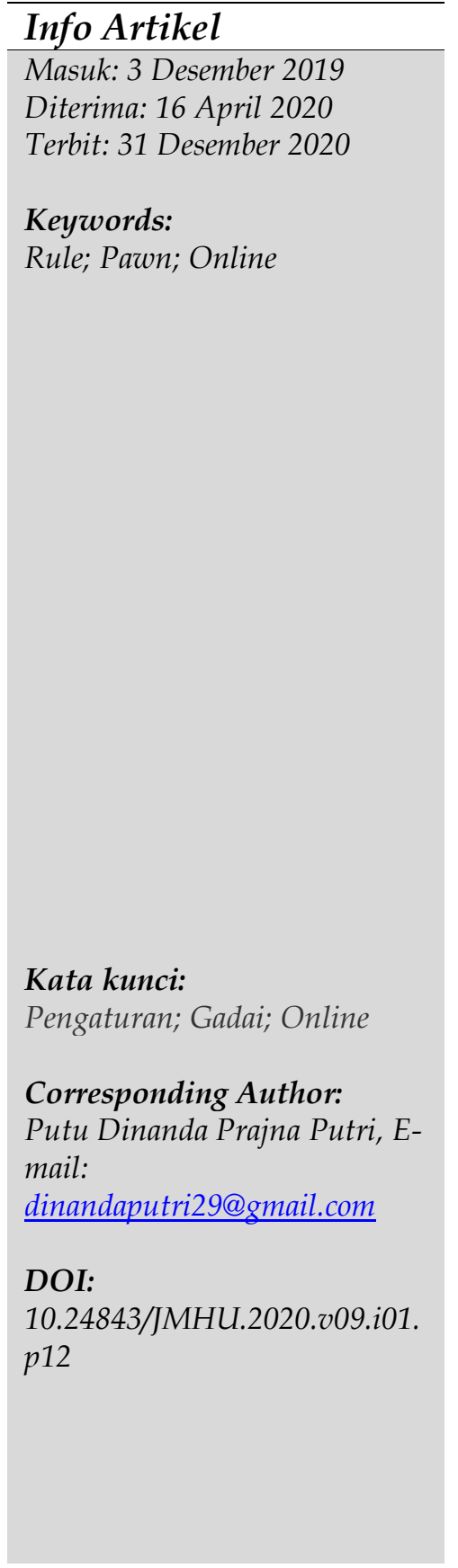

\begin{abstract}
On the 4.0 dimension like now the needs of the human economy are increasing. With so many economic needs of people now they have to pledge his economic goods. Economic development in an area can be measured by the velocity of money. The development of the era as it is now there is a new mechanism in the pawn that is the online pawn. The purpose of writing this article is to understand more deeply about the organization of pawn shops, especially this online pawn shop. This paper uses the normative legal research method. Normative legal research is used because of the vacuum of the norma. The approach used is the negotiation approach and the conceptual approach. The legal amendments used are summaries of primer legal proceedings, source of legal security law, and secondary material judgments. The legal material collection techniques used are argumentative techniques and descriptive analysis techniques. Online pawn there are two parties, namely the giver and the pawn recipient. The pawn agreement includes an additional agreement where the principal agreement is the credit agreement. the internet network is used in this online pawn system. Where is also electronic information which means the data has been processed and has been understood? There are no rules about online liens covering all the activities of online-based online business. There are numbered vacancies, so regulations are needed to prevent losses incurred by one party for another party.
\end{abstract}

\begin{tabular}{l} 
Abstrak \\
\hline Pada dimensi 4.0 seperti saat ini kebutuhan ekonomi manusia \\
semakin meningkat. Dengan banyaknya kebutuhan ekonomi \\
manusia saat ini membuat mereka harus menjaminkan barang \\
ekonomi miliknya. Perkembangan perekonomian pada suatu \\
daerah dapat diukur dari perputaran uangnya. Berkembangnya \\
zaman seperti saat ini terdapat mekanisme baru dalam gadai \\
yaitu gadai online. Tujuan penulisan artikel ini adalah untuk \\
memahami lebih mendalam tentang pengaturan Lembaga gadai, \\
khususnya gadai online ini. Tulisan ini menggunakan metode \\
penelitian hukum normative. Penelitian hukum normative \\
digunakan beranjak dari adanya kekosongan dalam aspek norma \\
hukum, dimana dalam peraturan perundang-undangan tidak \\
diatur secara spesifik terkait gadai online di Indonesia. \\
Pendekatan yang digunakan adalah pendekatan perundang- \\
undangan dan pendekatan konsep. Bahan hukum yang \\
digunakan adalah sumber bahan hukum primer, sumber bahan
\end{tabular}


hukum sekunder dan sumber bahan hukum tersier. Teknik pengumpulan bahan hukum yang digunakan adalah teknik argumentative serta teknik analisis deskriptif. Dalam gadai terdapat dua subjek hukum yang saling berkaitan erat yaitu pemberi gadai dan penerima gadai. Gadai termasuk perjanjian tambahan, sedangkan perjanjian pokoknya adalah perjanjian pinjam meminjam uang. Gadai online yaitu gadai yang menggunakan internet sebagai medianya, yang merupakan informasi elektronik yang merupakan data elektronik yang telah diolah dan dapat dipahami oleh orang yang mampu memahaminya. Tidak adanya Tidak adanya atau urgensinya pengaturan mengenai gadai online di Indonesia gadai online swasta maupun gadai online dari pemerintah yang menggunakan fasilitas jaringan internet yang berkaitan dengan bagaimana menyerahkan barangnya, menaksirkan barangnya, ruang lingkup wilayahnya usaha, kemitraannya serta izinnya, serta barang atau benda yang dapat digadaikan dalam hal ini terdapat kekosongan norma yang mengaturnya.

\section{Pendahuluan}

Pada dimensi 4.0 seperti saat ini kebutuhan ekonomi manusia semakin meningkat. Dengan banyaknya kebutuhan ekonomi manusia saat ini membuat mereka harus menjaminkan barang ekonomi miliknya. Dimensi 4.0 ini merupakan era digitalisasi yang menjadi bagian dari revolusi industry 4.0. Globalisasi merupakan suatu proses dimana tidak terdapat batasan atar wilayah dan terbentuk suatu sistem organisasi dan komunikasi antar masyarakat untuk mengikuti aturan yang sama. Perbedaan dimensi 4.0 dengan globalisasi dapat dilihat dari perkembangan teknologi yang digunakan, di dalam dimensi 4.0 seperti saat ini perkembangan teknologi sangat berperan utama dalam menjalankan kegiatan ekonomi dunia, dimensi 4.0 ini lebih ditandai dengan adanya robot, supercomputer, mobil pintar dan sebagainya, itulah yang dapat menjadi pembeda dengan zaman globalisasi yang hanya menghilangkan batasan antarwilayah dalam hal menjalankan kegiatan-kegiatan khususnya kegiatan perekonomian. Dimana dalam dimensi 4.0 ini adalah perubahan-perubahan mendasar di bidang industry pada khususnya, yang banyak menggunakan perkembangan teknologi yang mengarah pada otomasi dan pertukaran data terkini secara mudah, cepat dan efisien. Perkembangan perekonomian pada suatu daerah dapat diukur dari perputaran uangnya. Hadirnya Lembaga keuangan ini diperuntukkan agar dapat memberikan kemudahan pinjaman maupun pembiayaan ganti kerugian bagi masyarakat yang kesulitan memperoleh dana untuk melakukan usaha. Kemudahan tersebut dapat meningkatkan aktivitas produksi dan nantinya dapat meningkatkan kualitas hidup masyarakat. ${ }^{1}$ Dalam dimensi 4.0 sistem informasi sangat diperlukan untuk menunjang kebutuhan hidup manusia. Hubungan antara pengelolaan transaksi harian yang memberikan dukungan terhadap suatu operasional suatu organisasi yang bersifat majerial dengan strategi

\footnotetext{
${ }^{1}$ Disemadi, H. S., \& Wahyuni, R. A. E. (2019). Eksistensi dan Kebijakan Regulasi Perizinan Lembaga Keuangan Mikro Oleh Otoritas Jasa Keuangan. Jurnal Yustisiabel, 3(2), 106-117. https://doi.org/10.32529/yustisiabel.v3i2.384
} 
tertentu yang diperoleh dari suatu organisasi tertentu disebut dengan sistem informasi.. ${ }^{2}$

Sulitnya memperoleh uang yang cepat tanpa harus menjual barang-barang berharga yang dimiliki oleh seseorang atau kehilangan barang-barang tersebut, dapat dilakukan dengan menggadaikan barang-barang berharga tersebut, sehingga masyarakat dapat menggadaikannya ke Lembaga keuangan seperti pegadaian. Barang-barang yang digadaikan dapat diambil kembali apabila orang berutang telah melunasi utangnya atau pinjamannya. Kegiatan meminjamkan uang dengan menjaminkan barang-barang berharga milik orang yang berutang serta penebusan atas barang-barang tersebut dapat dilakukan setelah tenggang waktu yang telah disepakati dalam perjanjiannya. Perusahaan pegadaian bertujuan untuk memberikan pinjaman kepada seseorang yang sedang membutuhkan uang agar tidak meminjam dengan pihak-pihak yang tidak seharusnya seperti tukang rentenir. ${ }^{3}$

Dengan meningkatnya kebutuhan hidup masyarakat, sehingga keperluan dana atau uang yang diperlukan juga meningkat. Agar mendapatkan dana tersebut seseorang dapat melakukan perjanjian tambahan seperti perjanjian pegadaian ini, namun apabila ingin melakukan perjanjian ini harus dilakukan dengan syarat-syarat yang sudah ditentukan seperti dengan menyerahkan barang-barang berharga khususnya benda bergerak yang sudah menjadi jaminan dari perjanjian gadai tersebut. Penyerahan barang tersebut dilakukan pemberi gadai atau debitor kepada penerima gadai atau kreditor. Jika dilihat dari sisi hukumnya jaminan dari perjanjian pegadaian tersebut merupakan suatu kepastian hukum bagi penerima gadai atau kreditor yang menjamin bahwa pemberi gadai atau debitor akan memenuhi kewajibannya atau akan membayar utangnya kepada kreditor tersebut. ${ }^{4}$ Diantara pihak penerima gadai dan pemberi gadai tersebut mempunyai hak serta kewajibannya. Penerima gadai atau kreditor memiliki hak untuk menjual barang atau benda yang digadaikan oleh debitor atau pemberi gadai apabila si pemberi gadai atau debitor lalai dalam memenuhi kewajibannya sesuai dengan tenggang waktu yang telah di perjanjikan atau disebut dengan wanprestasi. Penjualan barang jaminan milik debitor tersebut dapat digunakan untuk melunasi utang dari si debitor tersebut. Masyarakat dalam menggadaikan barangnya untuk mendapatkan uang biasanya dilakukan di Lembaga pegadaian. Pegadaian merupakan Lembaga bukan bank tetapi termasuk Lembaga keuangan yang dapat menyalurkan kredit kepada masyarakat. Di Indonesia Lembaga pegadaian dibagi menjadi dua yaitu pegadaian milik negara yakni PT. Pegadaian atau Perseroan dimana ketentuannya diatur dalam peraturan pemerintah dan yang kedua adalah pegadaian milik swasta yang ketentuannya diatur dalam Peraturan Otoritas Jasa Keuangan Nomor 31/POJK.05/2016 tentang Usaha Pergadaian.

2 Muhammad, W. K. S. (2019). Perancangan Sistem Informasi Tingkat Kepuasan Pelayanan Nasabah Pada PT Pegadaian CP Panam Berbasis WEB. Jurnal Intra Tech, 3(2), 70-81. http://journal.amikmahaputra.ac.id/index.php/JIT/issue/view/6

${ }^{3}$ Adjie, H., \& Saputro, E. H. (2015). Perlindungan Hukum Bagi Pemilik Objek Gadai Atas Pelelangan Objek Gadai. Jurnal HUKUM BISNIS, 1(1). https://doi.org/10.33121/hukumbisnis.v1i1.57

4 Suari, N. P. W. M. S. (2019). Perluasan Pengaturan Gadai Setelah Dikeluarkannya Peraturan Otoritas Jasa Keuangan Tentang Usaha Pergadaian. Acta Comitas: Jurnal Hukum Kenotariatan, 4(1), 11-21. https://doi.org/10.24843/AC.2019.v04.i01.p02 
Gadai di Indonesia telah diatur dalam "Kitab Undang-Undang Hukum Perdata" (selanjutnya disebut dengan KUHPerdata) yang diatur dalam "Pasal 1150-Pasal 1161 KUHPerdata". Selain KUHPerdata, kelembagaannya diatur dalam "Peraturan Pemerintah Nomor 10 Tahun 1990" tentang Pegadaian. Dengan perkembangan zaman seperti saat ini serta meningkatnya kebutuhan manusia maka dikeluarkanlahnya "Peraturan Otoritas Jasa Keuangan Nomor: 31/POJK.05/2016" (selanjutnya disebut dengan POJK usaha pergadaian), dimana aturan ini menjadi dasar adanya gadai swasta. Dengan adanya POJK ini dapat mengisi kekosongan hukum mengenai pegadaian yang belum diatur secara spesifik serta ruang lingkupnya lebih luas dari aturan gadai lainnya. Selain itu dalam POJK ini diatur juga usaha pegadaian dengan prinsip syariah.

Dengan diterbitkannya POJK ini, telah memberikan pengaruh terhadap aturan mengenai hukum jaminan khususnya mengenai gadai di Indonesia. Dengan adanya aturan ini OKJ dapat melakukan pengawasan terhadap usaha-usaha pergadaian di Indonesia. Dengan adanya pengawasan tersebut diharapkan agar tercipta usaha-usaha pegadaian yang sehat serta dapat memberikan kepastian hukum dan perlindungan hukum bagi pihak-pihak yang terlibat di dalamnya. ${ }^{5}$

Berkembangnya zaman seperti saat ini terdapat mekanisme baru dalam gadai yaitu gadai online. Gadai online memberikan kemudahan bagi masyarakat untuk mendapatkan dana secara cepat, mudah dan efisien dibandingkan dengan gadai pada umumnya. Dalam hal ini kreditor atau penerima gadai berhak atas suatu barang atau benda bergerak milik debitor atau pemberi gadai sebagai jaminan untuk pelunasan utangnya disebut dengan gadai. Sedangkan online adalah suatu sistem yang menggunakan fasilitas jaringan internet untuk mengaksesnya.

Dengan perkembangan dunia digital seperti dimensi $4.0 \mathrm{ini}$, membuat usaha-usaha pegadaian terus berinovasi. Salah satu inovasi tersebut adalah dengan dikeluarkannya gadai dengan sistem online. Gadai dengan sistem online ini disebut dengan Pegadaian Digital Service (selanjutnya disebut dengan PDS) yang memiliki tujuan agar masyarakat dapat dengan mudah dan cepat melakukan transaksi apapun itu. Pinjam.co.id merupakan salah satu pergadaian berbasis online saat ini, dimana pinjam.co.id tersebut merupakan usaha gadai swasta yang sudah merambah ke dunia maya. Dalam hal ini terdapat dua hal yang sangat penting yang perlu diatur dalam sistem gadai online ini yaitu teknologi yang berkaitan dengan data dari konsumen yang harus dilindungi serta bisnis gadai tersebut.

Gadai online di Indonesia belum diatur secara spesifik dalam aturan yang ada di Indonesia. Gadai yang berbasis online ini secara hukum belum diatur secara tegas. Sehingga apabila terjadi sengketa diantara para pihak maka penyelesaiannya dapat menggunakan kesepakatan atau consensus yang telah disepakati oleh para pihak dalam perjanjian kredit sebagai perjanjian pokok serta perjanjian gadai sebagai perjanjian tambahannya dan tidak boleh bertentang dengan peraturan-peraturan yang berkaitan dengan gadai tersebut. Dengan adanya penjambaran di atas maka penulis sangat tertarik untuk mengangkat judul mengenai "Pengaturan Lembaga Gadai Online Dalam Dimensi 4.0 Di Indonesia", karena penulis melihat adanya kekosongan norma mengenai gadai online tersebut.

\footnotetext{
${ }^{5}$ Abubakar, L., \& Handayani, T. (2018). Telaah Yuridis Perkembangan Regulasi Dan Usaha Pergadaian Sebagai Pranata Jaminan Kebendaan. Jurnal Bina Mulia Hukum, 2(1), 80-92.
} 
Dengan melihat latar belakang di atas, maka dapat dikaji suatu permasalahan yaitu bagaimana pengaturan lembaga gadai online di Indonesia serta bagaimana akibat hukum apabila terjadi pelanggaran. Tujuan penulisan ini adalah untuk memahami lebih mendalam tentang pengaturan Lembaga gadai online khususnya gadai online di Indonesia serta mengetahui akibat hukum apabila terjadi pelanggaran terhadap gadai online tersebut.

\section{Metode Penelitian}

Dalam penulisan artikel ini digunakan metode penelitian hukum normatif, menggunakan metode ini karena terdapat kekosongan norma, karena dalam peraturan perundang-undangan di Indonesia tidak diatur secara tegas mengenai gadai online tersebut. Dalam KUHPerdata tidak diatur mengenai gadai online, dalam POJK Usaha Pergadaian belum mengatur mengenai gadai online, selain itu dalam Peraturan Pemerintah Nomor 10 Tahun 1990 tentang Pegadaian juga tidak mengatur mengenai gadai online tersebut. Dalam metode ini yang menjadi objek penelitiannya adalah norma hukum. ${ }^{6}$ penulisan ini menggunakan pendekatan perundang-undangan (statue approach) serta pendekatan konsep (conceptual approach). Penulisan ini juga menggunakan bahan hukum, bahan hukum yang digunakan adalah bahan hukum primer, bahan hukum sekunder serta bahan hukum tersier. Penulisan ini menggunakan teknik studi dokumen sebagai teknik pengumpulan bahan hukumnya dan menggunakan teknik analisi yaitu teknik argumentatif dan teknik analisis deskriptif.

\section{Hasil dan Pembahasan}

\subsection{Pengaturan Gadai Online Di Indonesia}

Lembaga keuangan yang bukan bank yang dimana kegiatan usahanya dapat menyalurkan kredit disebut dengan pegadaian. Dimana dengan cara menyalurkan kredit ini, pegadaian mendapatkan keuntungan atau laba dari bunga yang dipinjam serta biaya administrasi dan lain sebagainya. Terdapat empat unsur dalam kredit tersebut yaitu berupa rasa kepercayaan, adanya jangka waktu, adanya prestasi serta degree of risk. ${ }^{7}$

Dengan adanya jaminan dalam penyaluran kredit memiliki fungsi sebagai pengamanan penyaluran kredit tersebut. Perbedaan dalam memberikan jaminan dapat berupa jaminan menguasai benda serta jaminan yang tidak menguasai benda. Lembaga pergadaian ini merupakan salah satu Lembaga yang dapat memberikan rasa aman terhadap para pihak khususnya penerima gadai atau kreditor tersebut, dikatakan dapat memberikan rasa aman karena benda atau barang bergerak yang dijaminkan oleh debitor berada di bawah pengawasan atau penguasaan kreditor tersebut. Dalam gadai terdapat pengertian bahwa dengan adanya jaminan tersebut memberikan keyakinan kepada kreditor bahwa utangnya debitor akan dibayar,

\footnotetext{
${ }^{6}$ Diantha, I Made. (2016). Metodologi Penelitian Hukum Normatif. Jakarta: Prenada Media Group.p.12

7 Jaya, I. G. P., Utama, I. M. A., \& Westra, I. K. (2015). Kekuatan Hukum Sertifikat Hak Tanggungan Dalam Hal Musnahnya Obyek Hak Tanggungan Karena Bencana Alam. Acta Comitas: Jurnal Hukum Kenotariatan, 277-285. https://doi.org/10.24843/ AC.2017.v02.i02.p12
} 
pengertian ini dapat dikatakan sebagai hak kreditor dalam gadai yang sifatnya kebendaan. ${ }^{8}$

Pemberi gadai atau debitor dan penerima gadai atau kreditor merupakan dua subjek hukum dalam gadai. Gadai ini merupakan perikatan tambahan yang mengikuti perikatan utamanya, dimana perjanjian kredit atau perjanjian pinjam meminjam uang. Benda bergerak tersebut ada yang berwujud dan ada yang tidak berwujud. Jaminan yang baik adalah jaminan yang tidak melambatkan aktivitas usaha-usaha debitor sedangkan jaminan yang baik juga adalah jaminan yang dapat memberikan rasa yang aman terhadap kreditor bahwa piutangnya akan dikembalikan.

Benda yang dijaminkan dalam pegadaian adalah benda yang bersifat memberikan jaminan dan dapat menjamin bahwa pembayaran utang dari uang yang dipinjamkan tersebut akan kembali. Barang atau benda yang dikuasai tersebut merupakan suatu hak untuk menguasai, tetapi hak menguasai tersebut memiliki batasannya seperti hak tidak untuk memakai barang tersebut, tidak untuk dinikmati serta tidak melakukan pemungutan hasil barang atau benda yang digadaikan tersebut. Apabila utang telah dibayar setengah oleh debitor tidak akan menghapus hak gadai tersebut, sehingga gadai tetap melekat pada benda atau barang yang telah dijaminkan dalam gadai tersebut. Atau dengan kata lain benda atau barang yang digadaikan tidak dapat dibagi-bagi. Dalam KUHPerdata rumusan mengenai jaminan tersebut tidak diatur secara tegas atau spesifik. Tetapi pengertian jaminan dapat diartikan sebagai benda atau barang bergerak yang dimiliki debitor atau pemberi gadai baik benda atau barang tersebut telah ada ataupun yang akan ada, menjadi jaminan dalam perikatan atau perjanjian dari debitor atau pemberi gadai tersebut. Pengertian tersebut mengandung makna bahwa orang yang memiliki utang harus bertanggung jawab atas utangnya tersebut. Tanggung jawab tersebut dapat dilakukan dengan menyediakan harta kekayaannya baik itu benda atau barang bergerak maupun yang tidak bergerak untuk melunasi utangnya sekalipun itu dengan cara menjual harta kekayaannya. Jaminan tersebut berasaskan dengan asas kepercayaan yang termuat di dalam hukum perikatan, yang memiliki arti bahwa orang yang diberikan utang tersebut diberikan rasa kepercayaan bahwa utang yang diberikan akan dikembalikan dengan jangka waktu yang telah ditentukan oleh orang yang memberikan utang. Para pihak dalam perjanjian selain memiliki hak juga memiliki kewajiban, sama dengan perjanjian ini dimana orang yang memberikan utang dengan orang yang diberikan utang mempunyai kewajiban untuk taat dan memenuhi apa yang telah di tulis dalam perjanjian yang merupakan perwujudan dari tanggung jawab moral dan tanggung jawab hukum kedua belah pihak.

Perjanjian pokok seperti perjanjian kredit atau pinjam meminjam uang sebaiknya diikuti oleh dengan perjanjian tambahan seperti perjanjian dengan adanya jaminan. Salah satu bentuk dari perjanjian tambahan yang mengikuti perjanjian pokoknya adalah gadai. Dengan menggunakan sistem gadai pinjam meminjam uang dapat dilakukan dengan tahapan yang lebih mudah, karena pinjam meminjam uang melalui sistem gadai ini tidak melalui tahapan yang Panjang, sehingga pinjam meminjam dengan sistem gadai ini banyak diminati oleh masyarakat. Gadai secara umum dapat diartikan sebagai hak yang dimiliki oleh kreditur atau penerima gadai atas benda atau

\footnotetext{
8 Narasanti, I. A. G. Perlindungan Hukum Terhadap PT. Pegadaian (Persero) Dalam Hal Barang Jaminan Gadai Bukan Milik Debitur. Jurnal Magister Hukum Udayana (Udayana Master Law Journal), 5(1), 69-82. https://doi.org/10.24843/JMHU.2016.v05.i01.p07
} 
barang bergerak yang dimiliki oleh debitor atau pemberi gadai, sebagai jaminan atas utangnya terhadap kreditor atau penerima gadai. Selain itu kreditor atau penerima gadai memiliki kewenangan untuk mengambil pelunasan atau piutangnya dan mengatur eksekusi barang atau benda yang digadaikan tersebut, apabila debitor atau pemberi gadai tidak memenuhi kewajibannya.

Pengaturan gadai pemerintah atau milik negara diatur dalam peraturan pemerintah sedangkan gadai swasta diatur POJK tentang usaha pergadaian. Pegadaian milik negara ataupun pegadaian milik swasta berada di bawah pengawasan "Otoritas Jasa Keuangan" (selanjutnya disebut dengan OJK). Selain itu di dalam usaha pegadaian terdapat juga pegadaian dengan prinsip syariah. Usaha pergadaian tersebut dapat diartikan bahwa hak yang dimiliki suatu perusahaan pergadaian atas benda atau barang bergerak yang dijaminkan oleh debitor atas utang-utangnya.

Dengan kemajuan zaman seperti saat ini, kemajuan teknologi sangatlah berkembang, begitu juga dengan usaha pegadaian. Di zaman 4.0 ini gadai telah merambah ke dunia maya yang dibuktikan dengan munculnya gadai yang menggunakan jaringan internet atau yang disebut dengan gadai online. Gadai online merupakan gadai yang menggunakan fasilitas internet sebagai medianya, gadai online ini termasuk ke dalam informasi elektronik yang memiliki arti bahwa gadai online ini merupakan suatu data yang bersifat elektronik yang dapat dipahami oleh pihak-pihak yang akan menggunakannya. Mengenai informasi atau data yang bersifat elektronik ini dapat dilihat aturannya dalam "Undang-Undang Nomor 19 Tahun 2016 tentang Perubahan Atas Undang-Undang Nomor 11 Tahun 2011 tentang Informasi dan Transaksi Elektronik (selanjutnya disebut dengan UU ITE)". Dalam undang-undang ini diatur mengenai transaksi elektronik yang memiliki arti bahwa suatu perbuatan khususnya perbuatan hukum yang menggunakan teknologi seperti komputer sebagai medianya. Pengaturan mengenai sistem ataupun transaksi elektronik ini selain terdapat di dalam undang-undang terdapat juga dalam "Peraturan Pemerintah Nomor 82 Tahun 2012 tentang Penyelenggaraan Sistem dan Transaksi Elektronik (selanjutnya disebut dengan PP PSTE)". Dalam peraturan tersebut seseorang atau badan usaha yang melakukan penawaran produk dengan mempergunakan fasilitas internet atau sistem online diwajibkan memberikan informasi mengenai produknya secara benar dan lengkap. Menggunakan fasilitas komputer disebut juga sebagai suatu sistem elektronik yang berfungsi seperti menyiapkan, menganalisa, mengumpulkan, mengolah, menyimpan serta menyebarkan informasi yang sifatnya elektronik. Penyelenggara sistem elektronik tersebut dapat berupa negara, orang perorangan, badan usaha serta masyarakat.

Kreditor atau penerima gadai dan debitor atau pemberi gadai dalam gadai online tidak perlu berhadapan atau bertatap muka secara langsung, cukup dengan website gadai yang bersangkutan. Dalam gadai online barang atau benda bergerak yang dapat dijadikan jaminan sama seperti barang atau benda yang dijaminkan dalam gadai konvensional.

Gadai di Indonesia khususnya usaha pergadaian swasta memang sudah lama menjamur, hingga merambah ke dunia maya. Usaha pergadaian swasta yang merambah ke dunia maya salah satunya adalah pinjam..co.id. Pinjam..co.id merupakan gadai online yang pertama hadir di Indonesia. Melalui gadai online ini sesorang bisa mendaftarkan diri dan barang yang akan digadaikan secara online. Sistem kerja gadai online berbeda dengan gadai konvensional pada umumnya. Dalam 
gadai online, sistem kerjanya yaitu seseorang yang akan menggadaikan barangnya akan mendaftarkan dirinya terlebih dahulu dalam laman web yang mengadakan gadai online, apabila telah selesai mendaftarkan dirinya, pihak yang akan menggadaikan barangnya akan mengirimkan foto barang yang akan digadaikan dalam laman website gadai online tersebut setelah itu petugas gadai online akan menaksir nilai gadainya hanya melihat dengan foto barang yang dikirimkan oleh pihak yang akan menggadaikan barangnya. Apabila pihak-pihak tersebut telah menyepakatinya, maka kurir yang ditugaskan akan mengambil barang atau benda bergerak yang telah dijadikan jaminan dalam pegadaian tersebut. Selanjutnya uang hasil gadai akan langsung di transfer ke rekening bank pemberi gadai. Permasalahan terjadi apabila benda atau barang yang digadaikan oleh debitor tidak sesuai dengan foto yang dikirimkan ke kreditor. Barang gadai yang hanya dilihat melalui foto, belum tentu akan sama dengan yang dikenyataan, karena kekurangan-kekurangan barang tersebut tidak akan terlihat jelas dalam foto yang dilampirkan oleh debitor. Selain itu pihak yang ada di dalam gadai online tersebut tidak hanya antara pemberi gadai dan penerima gadai namun juga dengan pihak bank, apabila terjadi kesalahan dalam pengiriman uang yang ditransfer oleh pihak bank seperti kekurangan pengiriman uang yang telah disepakati oleh pihak pemberi gadai dan penerima gadai. Prosedur gadai online ini berbeda dengan gadai konvensional. Dalam gadai konvensional pihak pemberi gadai dan penerima gadai berhadapan langsung, sehingga apapun kesalahan ataupun kekurangan yang terjadi dapat diatasi langsung oleh para pihak, seperti kekurangan pembayaran, apabila terjadi kekurangan pembayaran pihak debitur dapat meminta langsung terhadap pihak kreditor tanpa harus berurusan dengan pihak bank. Selain itu persyaratan yang harus dilengkapi pada gadai konvensional sangatlah mudah. Sedangkan di dalam gadai online, apabila terjadi kekurangan dalam hal pembayaran dan/atau persyaratan administrasi lainnya, maka proses penyelesaiannya akan menggunakan waktu yang lama dibandingkan dengan gadai konvensional. Dengan prosedur gadai online seperti yang telah dijelaskan di atas maka sangat rentan akan terjadi pelanggaran yang dilakukan oleh salah satu pihak. Dalam hal ini dihimbau agar masyarakat lebih berhati-hati saat akan menggadaikan barangnya di pergadaian yang berbasis online. Karena payung hukum mengenai gadai online sangatlah penting untuk menjamin kerahasiaan data hingga penyimpanan barang pemberi gadai pada kondisi yang aman. Dalam hal ini kasus dalam gadai online belum didapatkan secara spesifik namun dalam gadai tersebut banyak terdapat gadai-gadai illegal yang mengharuskan masyarakat berhati-hati dalam memilih Lembaga pegadaian yang akan digunakan oleh masyarakat. Gadai-gadai illegal tersebut merupakan gadai liar yang tempat usahanya tidak mempunyai tempat untuk menyimpan barang gadai, penaksiran barang jaminan tidak tersertifikasi, bunga yang tinggi, uang kelebihan dari lelang tidak dikembalikan ke konsumen, barang jaminan tidak masuk asuransi, hanya menguntungkan pelaku usaha serta tidak memiliki izin. Gadai-gadai illegal yang seperti itulah yang dapat merugikan konsumen.

Teori hukum yang digunakan dalam penulisan ini adalah teori sistem hukum menurut Lawrence M.Friedman yang digunakan sebagai pisau analisis dalam permasalahan tulisan ini. Lawrence mengatakan bahwa berlakunya dan berhasil atau tidaknya penegakan hukum dengan benar terdapat tiga faktor yang mempengaruhinya yaitu struktur hukum, substansi hukum, serta budaya hukum. dimana struktur hukum merupakan aparat penegak hukumnya, subtansi hukum merupakan peraturannya sedangkan budaya hukumnya hukum yang hidup yang ditaati di dalam masyarakat. 
Dengan ketiga faktor di atas, dapat dilihat bahwa gadai online belum ada substansi hukum yang mengaturnya yang belum di buat oleh struktur hukumnya serta budaya hukumnya tidak akan terealisasikan dengan baik di dalam masyarakat. dalam penulisan ini lebih ditekankan dalam substansi hukumnya dimana di dalamnya terkandung norma hukum, aturannya serta pola perilaku nyata masyarakat yang berada di dalam suatu sistem. Dengan penjabaran di atas, agar sesuai dengan sistem hukum yang ada, gadai online ini diperlukan adanya pengaturan yang mengaturnya sehingga apabila terjadi suatu pelanggaran ataupun kerugian bagi salah satu pihak, aturan hukum yang telah memiliki kekuatan hukum mengikatlah yang dapat dijadikan pedoman dalam penegakan hukum tersebut.

Tidak adanya atau belum diaturnya secara tegas pengaturan mengenai gadai online di Indonesia. Baik itu gadai swasta maupun gadai milik negara atau gadai pemerintah. Dalam pengaturan gadai online tersebut perlu diatur mengenai penyerahan barangnya, bagaimana menaksir harganya, ruang lingkup wilayah usahanya, kemitraannya, izinnya serta barang apa yang dapat dan tidak dapat digadaikan. Dengan belum di aturnya gadai online tersebut terdapat kekosongan hukum dalam gadai berbasis online tersebut. ${ }^{9}$

\subsection{Akibat Hukum Apabila Terjadi Pelanggaran}

Perjanjian gadai merupakan perjanjian tambahan yang mengikuti perjanjian pokoknya, dimana perjanjian tersebut merupakan kesepakatan antara debitor atau pemberi gadai dan pihak kreditor atau penerima gadai. Dalam perjanjian gadai ini akan menyebabkan adanya hubungan hukum Dengan adanya hubungan hukum tersebut akan menimbulkan adanya akibat hukum berupa hak dan kewajiban. Apabila akibat hukum tersebut dilanggar oleh salah satu pihak dan menyebabkan kerugian, maka salah satu pihak yang dirugikan dapat melakukan penuntutan atas kerugiannya tersebut. Sehingga yang merugikan dapat dikenakan sanksi, dalam hal ini sanksi selalu dikaitkan dengan pelanggaran-pelanggaran norma atau nilai-nilai yang terdapat di dalam masyarakat, dimana pelanggaran tersebut mengakibatkan kerugian-kerugian terhadap pihak lainnya.

Hak-hak dan kewajiban-kewajiban merupakan akibat hukum dari hubungan hukum tersebut lahir ketika perjanjian disepakati oleh kedua belah pihak yang membuatnya. Dalam hal ini hak dari kreditor atau penerima gadai yakni mendapatkan pengembalian atas piutangnya beserta bunga yang telah disepakati dalam jangka waktu yang telah ditentukan serta dapat menjual barang atau benda yang dijadikan jaminan apabila pemberi gadai atau debitor lalai dalam melakukan kewajiban. Selain hak terdapat juga kewajiban kreditor atau penerima gadai yakni diwajibkan menjaga barang atau benda yang telah digadaikan kepadanya oleh debitor atau pemberi gadai, tidak menjadikan barang atau benda tersebut menjadi miliknya serta bertanggung jawab atas kerusakan-kerusakan terhadap barang atau benda yang di gadaikan apabila kerusakan itu terjadi akibat kelalaian debitor atau pemberi gadai. Sedangkan untuk

9 Hanifah, A., Santoso, B. S., \& Navianto, I. (2018). URGENSI PENGATURAN PERUSAHAAN GADAI SWASTA DENGAN SISTEM ONLINE. Al-Mustashfa: Jurnal Penelitian Hukum Ekonomi Syariah, 3(1), 30-41. https://badge.dimensions.ai/details/doi/10.24235/jm.v3i1.2935?domain=http://www.syek hnurjati.ac.id 
debitor atau pemberi gadai memiliki hak yakni mendapatkan uang dari kreditor atau penerima gadai, apabila utangnya sudah lunas beserta bunganya debitor atau pemberi gadai berhak atas pengembalian barang atau benda yang digadaikannya. Dengan adanya hak selalu diikuti dengan kewajiban, dimana kewajiban debitor atau pemberi gadai yakni memberikan barang atau benda yang telah dijaminkannya kepada kreditor atau penerima gadai, membayar utangnya beserta bunga-bunganya serta membayar biaya yang kreditor atau penerima gadai keluarkan dalam hal penyelamatan barang atau benda gadai tersebut.

Perusahaan pegadaian yang berbasis gadai swasta yang telah melakukan pelanggaran terhadap ketentuan yang diatur dalam POJK usaha pegadaian dapat dijatuhi sanksi yaitu berupa sanksi administrative yang dapat berupa peringatan, pembekuan aktivitas usaha, dibatalkannya persetujuan kegiatan usaha yang khususnya berdasarkan prinsip syariah, dicabutnya izin usaha. Selain itu gadai yang dikelola oleh negara juga dapat di jatuhi hukuman apabila telah terbukti melakukan pelanggaran terhadap aturan yang terkait dengan pegadaian tersebut.

Gadai online merupakan gadai yang sedang menjamur di zaman seperti saat ini dengan memanfaatkan kemajuan teknologi dalam penyelenggaraannya yaitu menggunakan jaringan internet dalam pengoperasiannya. Dalam menggunakan sistem online seperti ini orang atau badan usaha yang sengaja menyebarkan informasi yang tidak benar atau informasi yang bohong yang menimbulkan kerugian terhadap pihakpihak tertentu dapat dipidana dan dapat dikenakan denda.

Dengan adanya hukum diharapkan dapat memberi rasa aman terhadap masyarakat khususnya hak setiap orang dari orang-orang yang melanggarnya. Perlindungan hukum dapat dilakukan dengan saran perlindungan hukum yang memiliki sifat preventif yang bertujuan untuk mencegah terjadinya suatu sengketa. Selain itu terdapat juga sarana perlindungan hukum represif yang bertujuan untuk menyelesaikan sengketa yang terjadi dan memberikan sanksi apabila terjadinya pelanggaran. Di dalam gadai online ini sarana perlindungan hukum preventif dan sarana perlindungan hukum represif dapat digunakan, sarana perlindungan preventif dapat dilakukan dengan pencegahan yaitu dengan cara membuat aturan mengenai gadai online, sehingga apabila suatu perusahaan pergadaian akan membuat suatu situs tentang gadai online dapat didaftarkan melalui Kementerian Perizinan dan Kementerian Informasi dan Komunikasi sehingga apabila suatu perusahaan pegadaian akan melakukan pendaftaran gadai online miliknya dapat mendaftarkan situs gadai online tersebut. Gadai online yang sudah didaftarkan tersebut akan dievaluasi dengan beberapa persyaratan yang telah ditentukan dalam aturan yang mengaturnya. Apabila suatu gadai berbasis online yang telah memenuhi persyaratan yang telah ditentukan, maka Kementerian Perizinan bersama Kementerian Informasi dan Komunikasi dapat memberikan sertifikat elektronik yang sifatnya elektronik yang termuat tanda tangan elektronik serta identitas para pihak sebagai subjek hukum. Apabila suatu perusahaan pegadaian yang menyelenggarakan sistem gadai online telah memperoleh sertifikat elektronik berarti perusahaan pegadaian tersebut telah lulus tahap administrasi. Dengan adanya sertifikat elektronik yang dicantumkan dalam situs gadai online yang dimiliki suatu perusahaan pegadaian, sertifikat elektronik dapat sebagai trustmark atau tanda percaya. Melalui sertifikat elektronik ini perusahaan pegadaian yang menyelenggarakan gadai online adalah perusahaan gadai online yang dapat dipercaya dan telah mendapatkan sertifikasi dari Lembaga sertifikasi yang berwenang. Apabila 
terjadi pelanggaran dan menyebabkan kerugian terhadap masyarakat yang menggunakan gadai online, masyarakat sebagai pemberi gadai dapat mengajukan tuntutan agar perusahaan pegadaian yang menyelenggarakan gadai online dapat dikenakan sanksi sesuai dengan aturan yang berlaku. Pemberian sanksi ini merupakan sarana perlindungan hukum represif. Sanksi yang diberikan dapat berupa pencabutan izin usaha, penarikan sertifikat elektronik serta pemblokiran situs gadai online yang telah didaftarkan. Begitu juga sebaliknya apabila pemberi gadai yang melakukan pelanggaran, perusahaan pegadaian atau penerima gadai dapat mengajukan tuntutan dan pemberi gadai dapat dijatuhi sanksi sesuai dengan aturan yang berlaku.

\section{Kesimpulan}

Pengaturan mengenai gadai diatur dalam Pasal 1150 - Pasal 1160 KUHPerdata. KUHPerdata mengatur gadai pemerintah sedangkan gadai swasta diatur dalam POJK tentang usaha pegadaian. Gadai online merupakan kegiatan usaha yang memanfaatkan kemajuan teknologi sebagai cara menjalankannya. Melalui gadai online ini antara penerima gadai dan pemberi gadai tidak perlu bertemu langsung melainkan cukup dengan alamat situs yang telah disediakan, berbeda dengan gadai konvensional dimana antara penerima gadai dan pemberi gadai bertatap muka secara langsung untuk melakukan proses gadai tersebut. Substansi hukum dalam sistem hukum di Indonesia sangat diperlukan untuk menjamin kepastian hukum yang ada, sehingga peraturan perundang-undangan mengenai gadai online ini sangat diperlukan. Mengenai aturan gadai online tersebut belum ada substansi yang mengatur secara spesifik mengenai gadai yang berbasis online ini sehingga terdapat kekosongan norma.

Pergadaian yang menggunakan jaringan internet ini telah disesuaikan dengan kehidupan masyarakatnya yang milineal. Namun potensi risiko yang ada juga semakin besar, yang menimbulkan keresahan terhadap orang yang menggunakannya. Pelanggaran-pelanggaran yang terjadi terhadap pengguna gadai online ini dapat dilakukan dengan cara pencegahan maupun sanksi bagi pelanggarnya. Pencegahan dapat dilakukan dengan pembuatan sertifikat elektronik sedangkan untuk sanksi bagi pelanggarnya dapat dilakukan dengan pemblokiran website gadai online.

\section{Daftar Pustaka}

Buku

Diantha, I Made Pasek. (2016). Metodelogi Penelitian Hukum Normatif. Jakarta: Prenada Media Group.

Jurnal

Disemadi, H. S., \& Wahyuni, R. A. E. (2019). Eksistensi Dan Kebijakan Regulasi Perizinan Lembaga Keuangan Mikro Oleh Otoritas Jasa Keuangan. Jurnal Yustisiabel, 3(2), 106-117. https://doi.org/10.32529/yustisiabel.v3i2.384

Muhammad, W. K. S. (2019). Perancangan Sistem Informasi Tingkat Kepuasan Pelayanan Nasabah Pada PT Pegadaian CP Panam Berbasis WEB. Jurnal Intra Tech, 3(2), 70-81. http://journal.amikmahaputra.ac.id/index.php/JIT/issue/view/6 
Adjie, H., \& Saputro, E. H. (2015). Perlindungan Hukum Bagi Pemilik Objek Gadai Atas Pelelangan Objek Gadai. Jurnal Hukum Bisnis, 1(1). https://doi.org/10.33121/hukumbisnis.v1i1.57

Suari, N. P. W. M. S. (2019). Perluasan Pengaturan Gadai Setelah Dikeluarkannya Peraturan Otoritas Jasa Keuangan Tentang Usaha Pergadaian. Acta Comitas: Jurnal Hukum Kenotariatan, 4(1), 11-21. https://doi.org/10.24843/AC.2019.v04.i01.p02

Abubakar, L., \& Handayani, T. (2018). Telaah Yuridis Perkembangan Regulasi Dan Usaha Pergadaian Sebagai Pranata Jaminan Kebendaan. Jurnal Bina Mulia Hukum, 2(1), 80-92.

Jaya, I. G. P., Utama, I. M. A., \& Westra, I. K. (2015). Kekuatan Hukum Sertifikat Hak Tanggungan Dalam Hal Musnahnya Obyek Hak Tanggungan Karena Bencana Alam. Acta Comitas: Jurnal Hukum Kenotariatan, 277-285. https://doi.org/10.24843/AC.2017.v02.i02.p12

Narasanti, I. A. G. Perlindungan Hukum Terhadap PT. Pegadaian (Persero) Dalam Hal Barang Jaminan Gadai Bukan Milik Debitur. Jurnal Magister Hukum Udayana (Udayana Master Law Journal), 5(1), 69-82. https://doi.org/10.24843/JMHU.2016.v05.i01.p07

Hanifah, A., Santoso, B. S., \& Navianto, I. (2018). Urgensi Pengaturan Perusahaan Gadai Swasta Dengan Sistem Online. Al-Mustashfa: Jurnal Penelitian Hukum Ekonomi Syariah, 3(1), 30-41. https://badge.dimensions.ai/details/doi/10.24235/jm.v3i1.2935?domain=http ://www.syekhnurjati.ac.id

Peraturan Perundangan-Undangan

Kitab Undang-Undang Hukum Perdata

Peraturan Otoritas Jasa Keuangan Nomor 31/POJK.05/2016 Tentang Usaha Pergadaian

Undang-Undang Nomor 19 Tahun 2016 Tentang Perubahan Undang-Undang Nomor 28 Tahun 2011 Tentang Informasi dan Transaksi Elektronik, Tambahan Lembaran Negara Republik Indonesia Nomor 5952

Peraturan Pemerintah Republik Indonesia Nomor 82 Tahun 2012 Tentang Penyelenggaraan Sistem Dan Transaksi Elekteronik, Tambahan Lembaran Negara Republik Indonesia Nomor 5348 